\title{
ARTICLES
}

Novas tendências do mercado de trabalho

New trends in the labour market

\section{Benjamin Coriat}

Fundamentos para uma política de carreiras no contexto da reforma gerencial

Foundations for a career policy in the context of the managerial reform Marcelo de Matos Ramos

Sistema de avaliação e premiação por resultados da Embrapa Embrapa's performance evaluation system and premiums for outstanding results Alberto Duque Portugal, Antônio Flávio Dias Ávila, Elísio Contini e Geraldo da Silva e Souza

A presença do Estado no setor saúde no Brasil

The presence of the State in the health sector in Brazil

Susete Barboza França

Seguridade Social no Brasil

Social Secutiy in Brasil

Tatiana Wargas de Faria Baptista

\section{Ensaio}

O aprimoramento da conduta ética no serviço público federal

João Geraldo Piquet Carneiro 